\title{
Exposure of a single host (Chrysomy a megacephala) (Calliphoridae) to different quantities of female parasitoids (Nasonia vitripennis) (Pteromalidae)
}

\author{
Renata S. Mello ${ }^{1,2}$, Gonzalo E. Moya Borja ${ }^{3} \&$ Valéria M. Aguiar-Coelho ${ }^{4}$
}

${ }^{1}$ Programa de Pós-Graduação em Biologia Animal, Universidade Federal Rural do Rio de Janeiro, Rodovia BR 465, Km 47, $23890-000$ SeropédicaRJ, Brasil.mellorebio@yahoo.com.br

${ }^{2}$ Laboratório de Transmissores de Leishmanioses, Setor de Entomologia Médica e Forense, Pavilhão Lauro Travassos, IOC/FIOCRUZ, Avenida Brasil, 4365, Manguinhos 21040-900 Rio de Janeiro-RJ, Brasil. rsmello@ioc.fiocruz.br

${ }^{3}$ Departamento de Parasitologia Animal, Laboratório de Entomologia, Universidade Federal Rural do Rio de Janeiro, Rodovia BR 465, Km 47, 23890-000 Seropédica-RJ, Brasil.gemoya@ufrrj.br

${ }_{4}^{4}$ Departamento de Microbiologia e Parasitologia, Instituto Biomédico, Universidade Federal do Estado do Rio de Janeiro, Rua Frei Caneca, 94, 20211-040 Rio de Janeiro-RJ, Brasil.valerialed@yahoo.com.br

\begin{abstract}
Exposure of a single host (Chrysomya megacephala) (Calliphoridae) to different quantities of female parasitoids (Nasonia vitripennis) (Pteromalidae). The aim of this study was to verify the duration of the development period, number of parasitoids produced per pupa, parasitism rate and sex ratio of Nasonia vitripennis (Hymenoptera, Pteromalidae), when they were exposed to a single host: Chrysomya megacephala (Diptera, Calliphoridae). One pupa was exposed in glass tubes to different numbers of female parasitoids $(1,3,5,7,9$ and 11) during 48 h. Twenty replications/treatment were used, under controlled conditions ( $\mathrm{T}=27{ }^{\circ} \mathrm{C}$ day/ $25{ }^{\circ} \mathrm{C}$ night, $\left.60 \pm 10 \% \mathrm{RH}\right)$. Statistical analysis of the data was made using the ANOVA test and the "a posteriori" comparisons were made using the Tukey-HSD test (both tests with a significance level of 5\%). The duration of the development period was longer in treatments where a higher density of females per host was used. When five females per host were used, the mean number of parasitoids that emerged per pupa was higher. The data showed a tendency to a decrease in the amount of parasitoids emerged per host, especially of female, when used high quantities of female per host. Higher parasitism rates were observed in the 3:1 and 5:1 treatments and an increase in the percentage of unviable pupae was observed, probably due to an increase of female densities in the treatments, possibly a consequence of superparasitism.
\end{abstract}

KEYWORDS. Biological control; blowflies; parasitoids.

RESUMO. Exposição de um único hospedeiro (Chrysomya megacephala) (Calliphoridae) a diferentes quantidades de fêmeas parasitóides (Nasonia vitripennis) (Pteromalidae). O objetivo deste estudo foi verificar a duração do período de desenvolvimento, número de parasitóides produzidos por pupa, a taxa de parasitismo e a razão sexual de Nasonia vitripennis (Hymenoptera, Pteromalidae), quando submetidas ao hospedeiro Chrysomya megacephala (Diptera, Calliphoridae). Uma pupa foi exposta, em tubos de ensaio, a diferentes quantidades de fêmeas parasitóides $(1,3,5,7,9$ e 11) por um período de $48 \mathrm{~h}$. Foram realizadas 20 réplicas/ tratamento, sob condições controladas $\left(\mathrm{T}=27^{\circ} \mathrm{C}\right.$ dia/ $25^{\circ} \mathrm{C}$ noite, $60 \pm 10 \%$ UR). Foi utilizado ANOVA e teste Tukey-HSD para comparações posteriores (ambos com nível de significância 5\%). Foi observado um desenvolvimento mais lento nos tratamentos que utilizaram elevadas quantidades de fêmeas por hospedeiro. Quando utilizadas cinco fêmeas por hospedeiro, a média de parasitóides por pupa foi maior. Os dados mostraram que houve uma tendência para o decréscimo de parasitóides, especialmente de fêmeas, quando utilizadas elevadas quantidade de fêmeas por hospedeiro. As maiores taxas de parasitismo foram verificadas nos tratamentos 3:1 e 5:1, e foi observado um aumento na porcentagem de pupas inviáveis com a utilização de quantidades mais elevadas de fêmeas parasitóides por hospedeiro. Possivelmente causado pelo superparasitismo.

PALAVRAS-CHAVE. Califorídeos; controle biológico; parasitóides.

Calliphorids constitute a real problem in rural and urban environments where places with inadequate water and sewage infra-structure and buildup of decomposing organic material become nurseries for these insects and raise the probability of pathogen transmission and disease propagation (Furlanetto et al. 1984; Carvalho et al. 2005). Besides its role in disease propagation, calliphorids also act as vectors for Dermatobia hominis (Linnaeus Jr., 1781) (Marinho et al. 2003), and cause facultative or obligatory myiasis in humans and animals (Guimarães et al. 1983, Guimarães \& Papavero 1999).

Chrysomya megacephala (Fabricius, 1794) (Calliphoridae) is recorded as a species of medical-veterinary importance (Sukontason et al. 2005). The elevated incidence of this species in urban environments, in addition to their disease disseminating capacity classifies them as a pest and public health risk (Guimarães et al. 1979). Therefore, studies about biological aspects involving parasitoid / host associations have been conducted, aiming a future application in biological control of cycloraphan muscoids (Cardoso \& Milward-deAzevedo 1995; Cardoso \& Milward-de-Azevedo 1996; Mello \& Aguiar-Coelho 2009).

The parasitoid of cycloraphan muscoids, Nasonia 
vitripennis (Walker, 1836) is a gregarious ectoparasite of calliphorid, sarcophagid and muscid pupae (Whiting 1967). The parasitism success of these parasitoids is usually divided in hierarchic stages, which consist of locating the habitat and the host, evaluation and physiological regulation of the host (Brodeur \& Boivin 2004).

Female parasitoids cannot distinguish newly parasitized hosts from unparasitized ones, but after $60 \mathrm{~h}$ of parasitization, the parasitized puparium are rejected as oviposition sites (King $\&$ Rafai 1970). This discrimination between the parasitized and unparasitized is only possible after the ovipositor had drilled through the puparium and made contact with the pupa within (King \& Rafai 1970, King \& Ellison 2006). The value of this discrimination to the parasitoid is perhaps to prevent the second clutch being eaten or being unable to feed because the host has been rendered unsuitable in some way by the first clutch (King \& Rafai 1970).

The females that neglect host quality and ovipose in an already parasitized puparium, usually present consequences for their progeny, such as a low parasitoid production and reduced insects size, possibly due to the occurrence of superparasitism, that refers both to one female ovipositing repeatedly in a single host and to more than one female ovipositing in a single host (Wylie 1963, 1965; King 1987).

The present study aimed to verify the possible alterations of the parasitoid offspring, such as: duration of immature stage development period (period from oviposition to adult eclosion), number of parasitoids produced per pupa, sex ratio and percentage of parasitism, when one pupa of $C$. megacephala was exposed to different numbers of female parasitoids during $48 \mathrm{~h}$. Based on the proposal of discriminating parasitized puparium, the hypothesis of this study is that high proportions of parasitoid / host may cause the superparasitism. It may occur because the chances of successive ovipositions in the same host is higher when there is an increase of the number of females per host and also because the discrimination cannot occur during the first $60 \mathrm{~h}$ according to King \& Rafai (1970).

\section{MATERIALAND METHODS}

Insects. The colony of $C$. megacephala was established using traps described by Mello et al. (2007) containing sardines removed from the freezer $24 \mathrm{~h}$ before exposition. The traps were allocated next to the garbage in Rio-Zoo Foudation, Rio de Janeiro, and remained in the field during $48 \mathrm{~h}$. The methodology used for maintaining the stock colony followed the orientation described by Milward-de-Azevedo et al. (1995).

The parasitoids capture was also carried out at the RioZoo Foundation. For sampling, a netted cage $(15 \times 20 \mathrm{~cm})$ was used and the net allowed the entry of potential parasitoids. Still inside these cages, 100 C. megacephala pupae from the stock colony, varying from $0-24 \mathrm{~h}$-age, were exposed and putrefact bovine meat was dispensed as a source of apneumone (Cardoso \& Milward-de-Azevedo 1996). After 96 $\mathrm{h}$, the potentially parasitized hosts were collected and individualized in glass tubes $(50 \mathrm{~mL})$, sealed with cotton plugs. They were carried to the laboratory and maintained in acclimatized chamber until the emergence of parasitoids or dipterans. The identification of these individuals was made by the taxonomic description of Rueda \& Axtell (1985).

The parasitoids were transferred to glass cages $(1 \mathrm{~L})$ and fed with honey droplets adhered to a filter paper and watersoaked cotton. For $N$. vitripennis stock colony maintenance, C. megacephala pupae of up to $24 \mathrm{~h}$-age were regularly offered to the female parasitoids.

Bioassays. The experiment was conducted in an acclimatized chamber $\left(\mathrm{T}=27^{\circ} \mathrm{C}\right.$ day $/ 25^{\circ} \mathrm{C}$ night, $60 \pm 10 \%$ relative humidity and $14 \mathrm{~h}$ photoperiod). The wasps that were used measured from 2 to $2.5 \mathrm{~mm}$ and up to $24 \mathrm{~h}$. These females were previously maintained with males and fed with honey to increase the supply of maturated ovaries (Wylie 1965). C. megacephala pupae of up to $24 \mathrm{~h}$-age were used, and weighted in semi-analytical scale (up to $0.01 \mathrm{mg}$ ) in lots of ten pupae for weight standardization.

One pupa of C. megacephala was isolated in glasses tubes $(50 \mathrm{~mL})$ with different numbers of female parasitoids: one parasitoid /one host, three parasitoids / one host, five parasitoids / one host, seven parasitoids /one host, nine parasitoids / one host, eleven parasitoids / one host. Each treatment consisted of 20 replications, after $48 \mathrm{~h}$ female parasitoids were discarded and the pupae were kept isolated in the tubes until emergence of C.megacephala or $N$. vitripennis.

The pupae lots not exposed to parasitism and presenting the same experimental planning were used as control, with the purpose of verify the calliphorids natural mortality rate. Daily observations were made until the $25^{\text {th }}$ day after the emergence of the first parasitoid.

Statistical analysis. The sex ratio (proportion of females) was performed following Silveira Neto et al. (1976) defined by: $\mathrm{sr}=$ number of females / (number of females + number of males). The differences among the treatments were tested by ANOVA with a significance level of 5\% and post-test Tukey HSD. The parasitism percentage was defined by: $p=$ number of puparium with emerged parasitoids / (total number of puparium exposed to parasitism) x 100. An ANOVA test was used (with a significance level of 5\%) to analyze the possible differences in the duration of immature stage development period (female, male and sum of female and male) among the treatments and the possible differences in development time according to sex in each treatment. The possible differences in the number of parasitoids (female, male and sum of female and male) emerged per pupa among the different treatments were also tested. For a posteriori comparisons theTukey-HSD test was used (Magalhães \& Lima 2001).

\section{RESULTSANDDISCUSSION}

A significant difference was observed in the duration of the development period among the treatments (ANOVA: $\mathrm{F}_{5}$. ${ }_{1315}=978.86$ and $\left.\mathrm{p}<0.001\right)$. As the proportion of wasp per host 

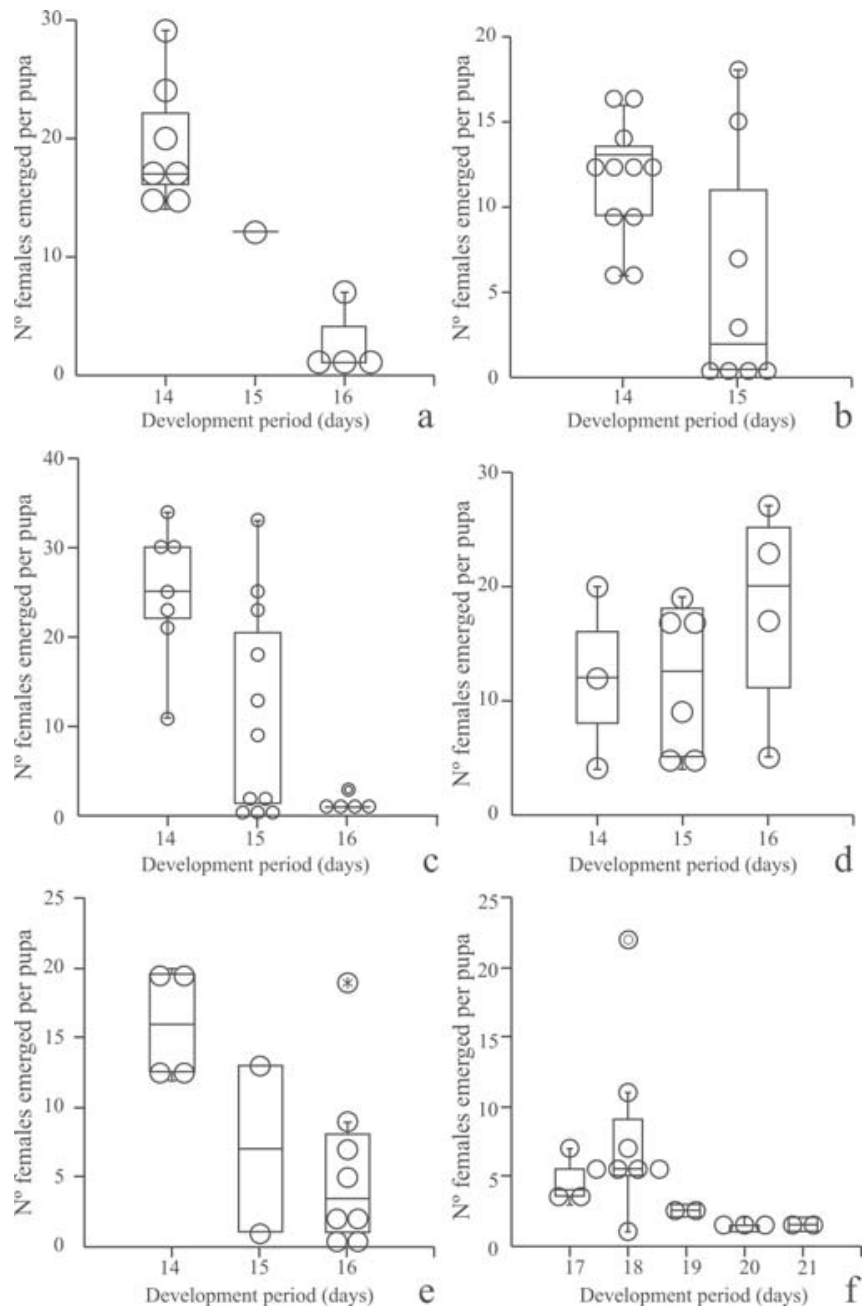

Fig. 1 a-f. Box-Plot combined with dot-density representing the number of female emerged per day from treatments where one host was exposed to different numbers of female parasitoids: (a) one, (b) three, (c) five, (d) seven, (e) nine and (f) eleven.

increased, the development period was slower. The most accelerated development period (sum of female and male) was observed in 1:1 and 3:1 treatments and the slower development period was observed in the 11:1 (Table I). Both males and females, analyzed separately, presented differences in the duration of development period among the treatments $\left(\mathrm{F}_{5}\right.$, ${ }_{284}=156.03, \mathrm{~F}_{5,1014}=824.30, \mathrm{p}<0.001$, respectively). A slower development period was observed in treatments with high proportion of wasp per host, both for female and male (Table I). Comparing the development period between female and male within each treatment a significant difference was observed only in the 7:1 treatment (Tukey test: $\mathrm{F}_{1,232}=4.92 ; \mathrm{p}$ $=0.027$ ), where the male had a faster development period than the female (Table I).

The parasitoids started to emerge in the $14^{\text {th }}$ day after exposure in all treatments (Fig. 1a-e and 2 a-e), except for parasitoids emerged of the 11:1 treatment (Fig. $1 \mathrm{f}$ and $2 \mathrm{f}$ ), which had a delay in the development and started the
Table I. Mean duration of immature stage development period of $N$. vitripennis (days) in treatments where one pupa was exposed to different numbers of female parasitoids (one, three, five, seven, nine and eleven)

\begin{tabular}{clll}
\hline \multirow{2}{*}{$\begin{array}{c}\text { Parasitoid/ } \\
\text { Host }\end{array}$} & \multicolumn{3}{c}{$\begin{array}{l}\text { Duration of immature stage development period (days) } \\
\text { (mean } \pm \text { SE) }\end{array}$} \\
\cline { 2 - 4 } & Females & Males & Female and Male \\
\hline $1: 1$ & $14.22 \pm 0.55 \mathrm{E}, \mathrm{a}$ & $14.42 \pm 0.77 \mathrm{C}, \mathrm{a}$ & $14.23 \pm 0.57 \mathrm{E}, \mathrm{a}$ \\
$3: 1$ & $14.26 \pm 0.44 \mathrm{D}, \mathrm{E}, \mathrm{a}$ & $14.25 \pm 0.44 \mathrm{C}, \mathrm{a}$ & $14.26 \pm 0.44 \mathrm{E}, \mathrm{a}$ \\
$5: 1$ & $14.44 \pm 0.54 \mathrm{D}, \mathrm{a}$ & $14.43 \pm 0.55 \mathrm{C}, \mathrm{a}$ & $14.45 \pm 0.54 \mathrm{D}, \mathrm{a}$ \\
$7: 1$ & $15.20 \pm 0.75 \mathrm{~B}, \mathrm{a}$ & $14.95 \pm 0.73 \mathrm{~B}, \mathrm{~b}$ & $15.14 \pm 0.75 \mathrm{~B}, \mathrm{a}$ \\
$9: 1$ & $14.84 \pm 0.93 \mathrm{C}, \mathrm{a}$ & $14.99 \pm 0.85 \mathrm{~B}, \mathrm{a}$ & $14.89 \pm 0.90 \mathrm{C}, \mathrm{a}$ \\
$11: 1$ & $19.09 \pm 0.84 \mathrm{~A}, \mathrm{a}$ & $18.73 \pm 0.46 \mathrm{~A}, \mathrm{a}$ & $19.04 \pm 0.81 \mathrm{~A}, \mathrm{a}$ \\
\hline
\end{tabular}

Within a column means followed by same capital letters and/or within a line means followed by same tiny letters, do not differ significantly at the 5\% level according to Tukey's HSD.

emergence only in the $17^{\text {th }}$ day after exposure to female parasitoids. The peak of emergency were observed in $14^{\text {th }}$ day for 1:1 (fig. $1 \mathrm{a}$ and $2 \mathrm{a}$ ), 3:1 (fig. $1 \mathrm{~b}$ and $2 \mathrm{~b}$ ), 5:1 (fig. $1 \mathrm{c}$ and 2 c) and 9:1 treatments (Fig. 1 e and 2 e). The 7:1 treatment (Fig. $1 \mathrm{~d}$ and $2 \mathrm{~d}$ ) had a peak of emergency in the $15^{\text {th }}$ and $16^{\text {th }}$ days and the 11:1 treatment had a peak of emergency in $18^{\text {th }}$ day (Fig. $1 \mathrm{f}$ and $2 \mathrm{f}$ ).

Legner \& Gerlin (1967) observed that N. vitripennis, maintained at $26^{\circ} \mathrm{C}$ and $55 \% \mathrm{RH}$, emerged from the $13^{\text {th }}$ to the $15^{\text {th }}$ day after host exposure to parasitoids. Moreira et al. (1996) observed in two distinct generations of $N$. vitripennis $\left(9^{\text {th }}\right.$ and $\left.62^{\text {nd }}\right)$, using proportion of 30 female parasitoids/ 120 pupae (temperature ranging $26^{\circ} \mathrm{C}$ to $30^{\circ} \mathrm{C}$ ), that the emergence initiated after the $12^{\text {nd }}$ day. Cardoso \& Milward-de-Azevedo (1995) studied different proportions of parasitoids / host ranging from 1 to 4 hosts exposed to one female during $48 \mathrm{~h}$ and verified a mean development period of 13 days both for male and female, but did not observe significant differences among the treatments. Schmit (1986) observed, in N. vitripennis, maintained at $27^{\circ} \mathrm{C}$, a mean duration of development period of 13 days, using Chrysomya rufifacies (Macquart, 1842) as host.

Thus, the duration of the development period of $N$. vitripennis observed in this study is according to the results of previous studies, although most of these earlier studies presented a mean of 13 days of development period and the parasitoids initiated the emergence ranging from the $12^{\text {nd }}$ to the $13^{\text {th }}$ day. However, in this study, a mean development period of 14 days was observed in almost all treatments, although a slower development period with increase of proportions of wasps per host was verified, mainly from eleven female parasitoids /one host treatment. Thus, it was possible to observe that the duration of the development period was potentially influenced by the proportion of wasp/ host, since the other factors that could have influenced the development were controlled, such as environmental conditions.

According to King \& Rafai (1970) the discrimination of parasitized host does not occur during the first $60 \mathrm{~h}$, then, as seen in this study, the parasitism was during $48 \mathrm{~h}$ when the females possibly could not detect the parasitized host. 

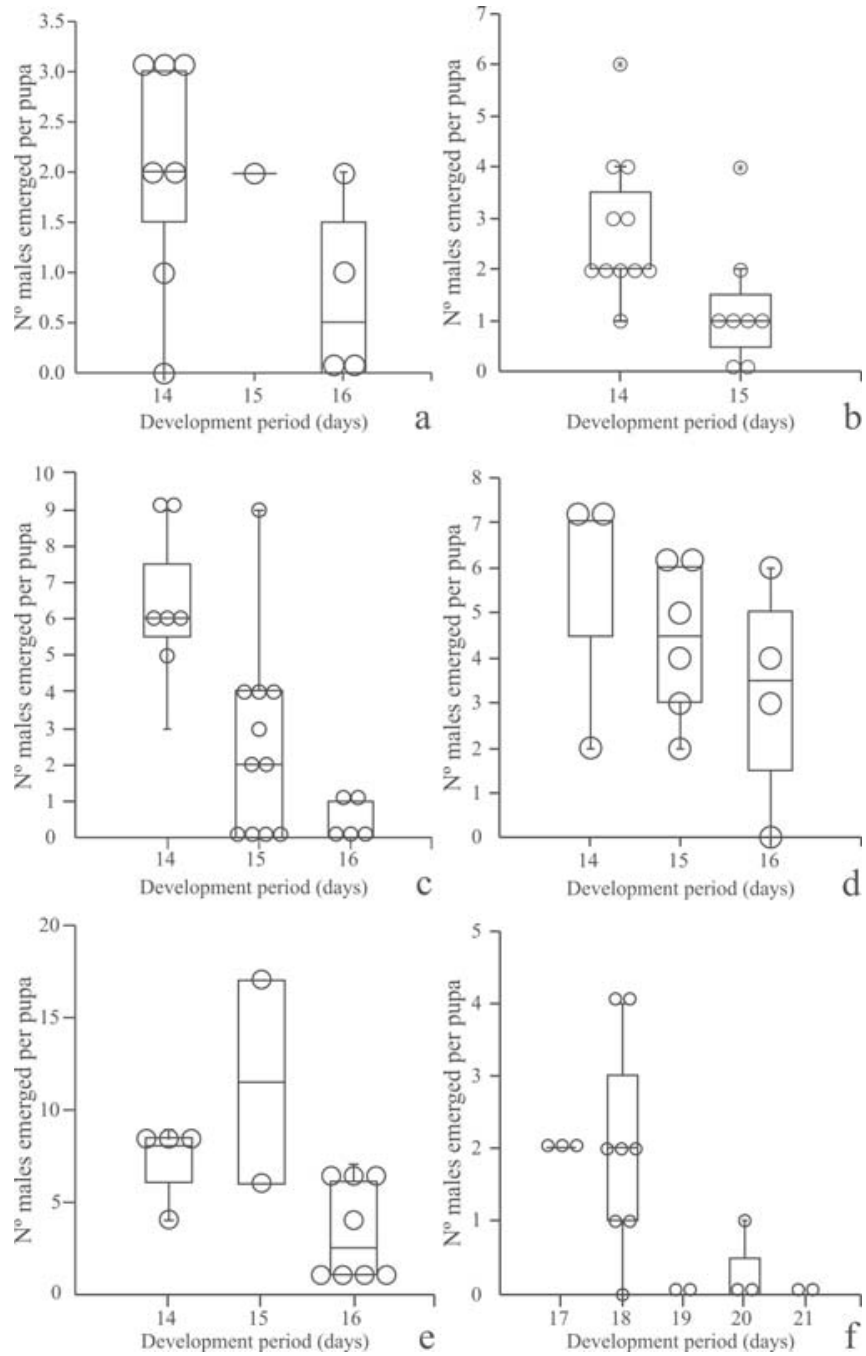

Fig. 2 a-f. Box-Plot combined with dot-density representing the number of male emerged per day from treatments where one host was exposed to different numbers of female parasitoids: (a) one, (b) three, (c) five, (d) seven, (e) nine and (f) eleven.

Therefore, the chances for the occurrence of superparasitism (when a second wasp lays eggs in a previously parasitized host), are higher mainly when hosts were exposed to high densities of female parasitoids. According to Wylie $(1963,1965)$ the superparasitism can provoke a reduction in the offspring size and /or death due to competition for food source by larvae and suggests that this can provoke a delay in the development period.

The mean number of parasitoids (sum of males and females) emerged per pupa from different treatments varied significantly (ANOVA: $\mathrm{F}_{5,53}=9.68, \mathrm{p}<0.001$ ) (Table II). The higher mean number of parasitoids emerged from each pupa was observed in the 5:1 treatment, differing significantly from all the other associations, except from 7: 1. As a consequence of this treatment there was a progressive reduction of offspring size, however it was not statistically different from treatments with lower proportions of females such as 1:1 and 3: 1. This was observed both for females and males analyzed separately (Fig. 3).

According to Slansky \& Scriber (1985), the best performance of gregarious insects is reached in a range of specific density and a decline can occur above or below this range, due to induction of micro-environmental conditions not favorable to development of these insects. Wylie (1965) observed that parasitized hosts with high densities of eggs leads to lower viability of parasitoids, attributing this fact as a consequence of superparasitism. In this study, the number of eggs on the pupae was not quantified, but a reduction in the production of parasitoids from the 7:1 treatment was observed and in addition to the delay of the development period it suggests that this may be related to the occurrence of superparasitism.

Barbosa et al. (2008) studied different proportions of female parasitoids ( $N$. vitripennis) per host (Cochliomyia macellaria (Fabricius, 1805) ranging from one to five. These authors did not verify significant differences in the number of parasitoids produced per pupa among the treatments, but they considered that males were more influenced than females because they presented a slower development with a high proportion parasitoid/host. In the present study the development period, both for male and female, was influenced by different proportions of parasitoid per host.

The number of females were significantly higher than males in all treatments $(\mathrm{p}<0.05)$, except in the 9:1 treatment (Tukey test: $\left.F_{1,16}=3.77 ; p=0.07\right)$. There was a female-biased sex ratio in all treatments, although, an increase in the proportion of

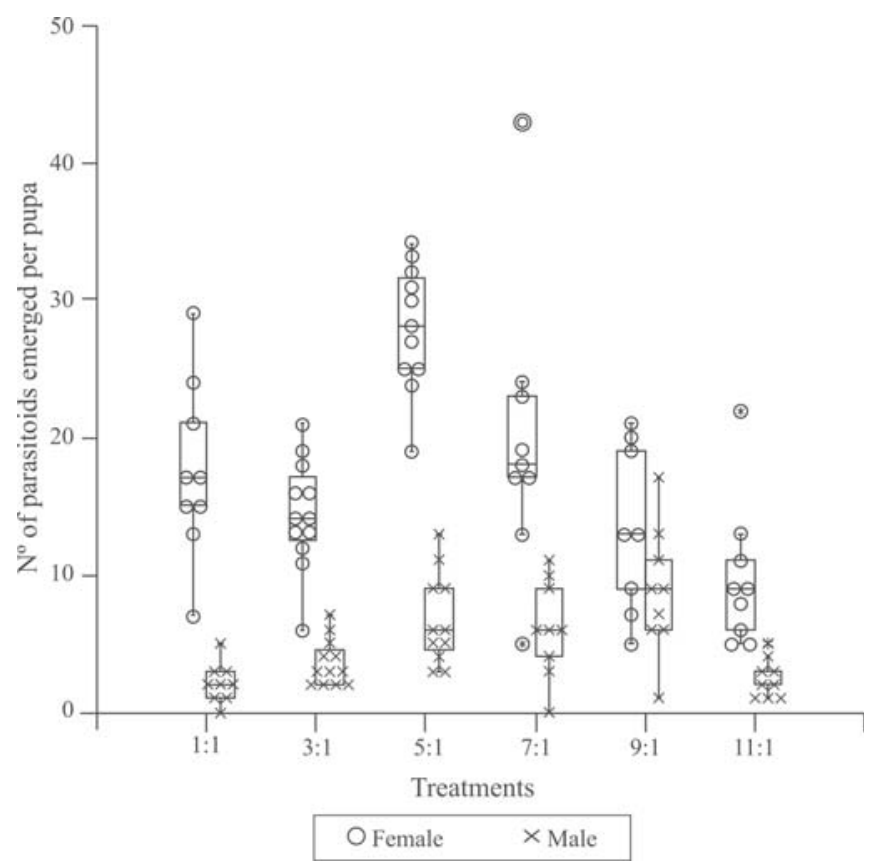

Fig. 3. Box-Plot combined with dot-density representing the number of females and males parasitoids emerged per pupa from treatments where one host was exposed to different numbers of female parasitoids (one, three, five, seven, nine and eleven). 


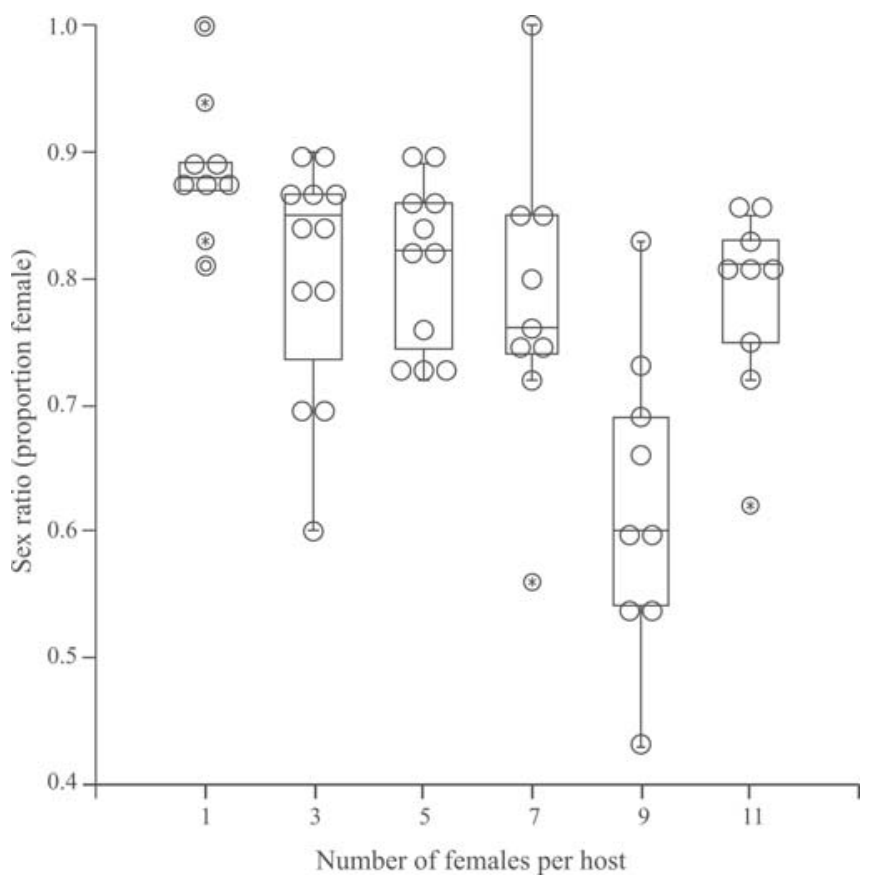

Fig. 4. Box-Plot combined with dot-density representing the sex ratio from treatments where one host was exposed to different numbers of female parasitoids (one, three, five, seven, nine and eleven).

male in treatments with high densities of female per host has occurred as in the 9:1 treatment (ANOVA: $\mathrm{F}_{5,53}=8.198, \mathrm{p}<$ 0.001) (Table II, Fig. 4).

Many studies attribute the ability of sex control to female parasitoids by controlling egg fertilization: sons develop from unfertilized eggs and daughters from fertilized eggs (King 1992). Some factors can alter offspring sex ratios such as: age of foundresses (mothers of the observed generation) or the number of days since insemination, extreme temperature, decreasing host size, age and quality, the number of other female wasps present and the number of progeny per host (King 1987).

Females, in general, invest in higher male proportions when they dispute in patch with other females, so, they possibly increase the chances of one of their sons to copulate with

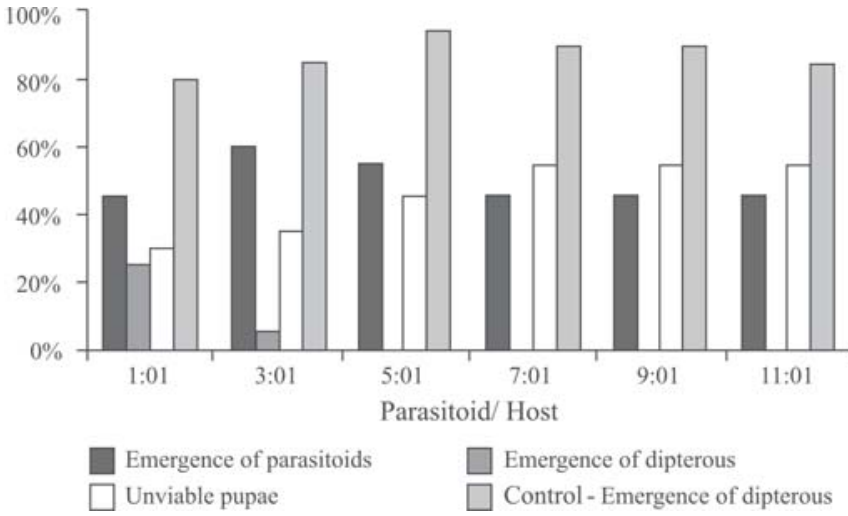

Fig. 5. Percentage of parasitized pupae (emerged parasitoids), pupae not parasitized (emerged dipterous), and unviable pupae (hosts producing neither fly nor parasitoids), when one pupa was exposed to different numbers of female parasitoids (one, three, five, seven, nine and eleven).

other females in the local of emergence. It is one of the consequences of the local mate competition (LMC) theory proposed by Hamilton (1967). LMC models assume that mating is local. When only one female oviposits in a patch, all the male offspring emerging from that patch will be brothers. In this situation, selection is predicted to favor mothers that produce only enough sons to inseminate all locally available females. In contrast, when multiple females lay in a patch, not all the males that are emerging from a patch will be brothers. Therefore, producing an increased proportion of sons, a mother can increase the chances of her own sons, and not another mother's son, will inseminate available females (King 1992)

The LMC can be formalized with the prediction that the unbeatable sex ratio (proportion of males; r) on a patch is $r=$ $(N-1) / 2 N$, where $N$ is the number of foundress females that lay eggs on the patch (Reece et al. 2004). There is considerable evidence from a variety of organisms that this prediction can explain sex ratio, and also that individuals facultatively adjust their offspring sex ratios in response to the number of females laying eggs per patch (King 1987).

Werren (1983) investigated the sex ratio dynamics of $N$. vitripennis on aggregated rather than isolated hosts exposed to different numbers of female wasps ranging from 1 to 12 . The

Table II. Mean of parasitoids numbers emerged per pupa, sex ratio from treatments where one pupa was exposed to different numbers of female parasitoids (one, three, five, seven, nine and eleven).

\begin{tabular}{cllll}
\hline Parasitoid/ Host & \multicolumn{2}{l}{$\begin{array}{l}\text { Sex ratio } \\
\text { (Mean } \pm \text { SE) }\end{array}$} & \multicolumn{2}{c}{ Number of parasitoid emerged per pupa (Mean \pm SE) } \\
\cline { 2 - 5 } & & Female & Male & Total (Female + Male) \\
\hline $1: 1$ & $0.88 \pm 0.03 \mathrm{~A}$ & $17.56 \pm 2.07 \mathrm{~B}, \mathrm{C}, \mathrm{a}$ & $02.38 \pm 0.98 \mathrm{C}, \mathrm{b}$ & $19.67 \pm 2.65 \mathrm{~B}, \mathrm{C}$ \\
$3: 1$ & $0.80 \pm 0.03 \mathrm{~A}$ & $14.42 \pm 1.79 \mathrm{~B}, \mathrm{C}, \mathrm{a}$ & $03.42 \pm 0.80 \mathrm{~B}, \mathrm{C}, \mathrm{b}$ & $17.83 \pm 2.29 \mathrm{~B}, \mathrm{C}$ \\
$5: 1$ & $0.81 \pm 0.02 \mathrm{~A}$ & $28.00 \pm 1.87 \mathrm{~A}, \mathrm{a}$ & $06.73 \pm 0.84 \mathrm{~A}, \mathrm{~B}, \mathrm{~b}$ & $34.73 \pm 2.39 \mathrm{~A}$ \\
$7: 1$ & $0.78 \pm 0.02 \mathrm{~A}$ & $19.89 \pm 2.07 \mathrm{~A}, \mathrm{~B}, \mathrm{a}$ & $06.88 \pm 0.98 \mathrm{~A}, \mathrm{~B}, \mathrm{~b}$ & $26.00 \pm 2.65 \mathrm{~A}, \mathrm{~B}$ \\
$9: 1$ & $0.62 \pm 0.03 \mathrm{~B}$ & $13.56 \pm 2.07 \mathrm{~B}, \mathrm{C}, \mathrm{a}$ & $08.78 \pm 0.93 \mathrm{~A}, \mathrm{a}$ & $20.56 \pm 2.65 \mathrm{~B}, \mathrm{C}$ \\
$11: 1$ & $0.78 \pm 0.03 \mathrm{~A}$ & $09.78 \pm 2.07 \mathrm{C}, \mathrm{a}$ & $02.44 \pm 0.93 \mathrm{C}, \mathrm{b}$ & $12.22 \pm 2.65 \mathrm{C}$ \\
\hline
\end{tabular}

Within a column means followed by same capital letters and/or within a line means followed by same tiny letters, do not differ significantly at the $5 \%$ level according to Tukey's HSD. 
data showed sex ratios of the progeny from each patch as a function of the number of contributing foundresses: the proportion of sons increased with increasing number of foundresses. The similar results were observed in the present study, where there was an increase of sons in the treatments with higher number of females per host such as the 9:1 treatment.

Werren (1983) also observed a difference of fitness (and mortality) between sons and daughters and states that when hosts are limited, females may overparasitize them, which causes first stuntedness and then mortality of daughters. Other studies report that males need lower recourse quality and quantity than females to reach maturity; consequently, in the condition of superparasitism, an increase in proportions of males can promote the survival of offspring (King \& Hopkins 1963).

A parasitism percentage ranging from 45 to $60 \%$ was observed, and the higher percentages were verified in the 3:1 and 5:1 treatments. Additionally, there was an increase of unviable pupae frequency when high proportions of parasitoids / host were used (Fig. 5). These data supported the occurrence of superparatism, since in these conditions the trend is that neither the parasitoid nor the host emerges, leading to a high frequency of unviable pupae. Some studies suggest that the high frequency in unviable pupae is caused by superparasitism and/ or deleterious effects in the puparium rupture caused by parasitoid females (Cardoso \& Milwardde-Azevedo 1995).

Brodeur \& Boivin (2004) observed that, when the probability of a female finding a host is lower than the probability of winning the competition with other females, it is always an advantage to parasitize that host, even if it is already parasitized, increasing the chances of the occurrence of superparasitism. This could be observed in the present study, when the proportion parasitoid/host was greater than one (wasp/host $>1$ ). The possible consequences can be the increase of unviable pupae (neither the parasite nor the host emerges), decreased offspring size per pupa and delay in the development period.

Based on the results herein presented it is possible to state that the population density of female parasitoids can affect the offspring and can be damaging. This suggests that these consequences lead to the occurrence of superparasitism, mainly, when high proportions of female parasitoids per host were used. Thus, biological control programs of muscoid dipterans that wishes to breed parasitoids before field release, must avoid conditions that propitiates the occurrence of this type of parasitism.

Acknowledgements. To CAPES for the master's scholarship given to the first author. To FINEP for the financial support. To Angélica Maria Penteado Martins Dias (Universidade de São Carlos, São Paulo state) for confirming our identification of the wasp $N$. vitripennis. To Marina Vianna Braga (IOC/FIOCRUZ) by review of the English in the manuscript.

\section{REFERENCES}

Barbosa L. S.; M. C. Couri \& V. M. Aguiar-Coelho. 2008. Desenvolvimento de Nasonia vitripennis (Walker, 1836) (Hymenoptera: Pteromalidae) em pupas de Cochliomyia macellaria (Fabricius, 1775) (Diptera: Calliphoridae), utilizando diferentes densidades do parasitóide. Biota Neotropica 8: 49-53.

Brodeur, J. \& G. Boivin. 2004. Functional ecology of immature parasitoids. Annual Review of Entomology 49: 27-49.

Cardoso, D. \& E. M. V. Milward-de-Azevedo. 1995. Influência de densidade de Chrysomya megacephala (Fabricius) (Diptera: Calliphoridae) sobre a capacidade reprodutiva de fêmeas nulíparas de Nasonia vitripennis (Walker) (Hymenoptera, Pteromalidae). Revista Brasileira de Entomologia 39: 779-786.

Cardoso, D. \& E. M. V. Milward-de-Azevedo. 1996. Aspectos da biologia de Nasonia vitripennis (Walker), (Hymenoptera: Pteromalidae) em pupas de Chrysomya megacephala (Fabricius) e C. albiceps (Wiedemann) (Diptera: Calliphoridae), sob condições de laboratório. Revista Brasileira de Entomologia 40: 143-146.

Carvalho, A. R.; J. M. d'Almeida \& R. P. Mello. 2005. Dinâmica Populacional e Parasitismo de Himenópteros Parasitóides de Chrysomya megacephala (Fabricius) (Diptera: Calliphoridae), no Rio de Janeiro, RJ. Revista Brasileira de Entomologia 49: 118122

Furlanetto, S. M. P.; M. L. C. Campos \& C. M. Hársi. 1984. Microorganismos enteropatogênicos em moscas africanas pertencentes ao gênero Chrysomya (Diptera, Calliphoridae) no Brasil. Revista de Microbiologia 15: 170-174.

Guimarães, J. H; A. P. Prado \& G. M. Buralli. 1979. Dispersal and distribuition (Diptera, Calliphoridae). Revista Brasileira de Entomologia 23: 245-55.

Guimarães, J. H.; N. Papavero \& A. P. Prado. 1983 As miíases na região Neotropical: identificação, biologia e bibliografia. Revista Brasileira de Zoologia 1:239-416.

Guimarães, J. H. \& N. Papavero. 1999. Myiasis Caused by Facultative Parasites. In: Myiasis in man and animals in the Neotropical Region. Plêiade, Bibliographic database, São Paulo, 35 p.

Hamilton, W. D. 1967. Extraordinary sex ratios. Science 156: 477488.

King, P. E. \& C. R. Hopkins. 1963. Length of life of the sexes in Nasonia vitripennis (Walker) (Hymenoptera, Pteromalidae) under conditions of starvation. Journal of Experimental Biology 40: $751-761$.

King, P. E. \& J. Rafai. 1970. Host discrimination in a gregarious parasitoid Nasonia vitripennis (Walker) (Hymenoptera: Pteromalidae). Journal of experimental Biology 53: 245-254.

King, B. H. 1987. Offspring sex ratios in parasitoid wasps. Quarterly Review of Biology 62: 362-396.

King, B. H. 1992. Sex-ratios of the wasp Nasonia vitripennis from selfversus conspecifically-parasitized hosts: local mate competition versus host quality models. Journal of Evolutionary Biology 5 : $445-455$.

King, B. H. \& J. H. Ellison. 2006. Resource quality affects restlessness in the parasitoid wasp Nasonia vitripennis. Entomologia Experimentalis et Applicata 118: 71-76.

Legner, E. F. \& D. Gerlin. 1967. Host-feeding and oviposition on Musca domestica by Spalangia cameroni, Nasonia vitripennis, and Muscidifurax raptor (Hymenoptera: Pteromalidae) influences their longevity and fecundity. Annals of the Entomological Society of America 60: 678-690.

Magalhães, M. N \& A. C. P. Lima. 2001. Noções de Probabilidade e Estatística. 3. ed, São Paulo, IME-USP, 392 p.

Marinho, C. R.; L. S. Barbosa; A. C. G. Azevedo; M. M. C. Queiroz; M. A. Valgode \& V. M. Aguiar-Coelho. 2003. Hemilucilia segmentaria (Fabricius, 1805) (Diptera: Calliphoridae) as New Biological Vector of Eggs of Dermatobia hominis (Linnaeus Jr., 1781) (Diptera: Oestridae) in Reserva Biológica do Tinguá, Rio de Janeiro, Brazil. Memórias do Instituto Oswaldo Cruz 98: 937-938.

Mello, R. S. \& V. M. Aguiar-Coelho. 2009 Durations of immature stage 
development period of Nasonia vitripennis (Walker) (Hymenoptera, Pteromalidae) under laboratory conditions: implications for forensic entomology. Parasitology Research 104: 411-418.

Mello, R. S; M. M. C. Queiroz \& V. M. Aguiar-Coelho. 2007. Population fluctuations of calliphorid species (Diptera: Calliphoridae) in the Biological Reserve of Tingua, sate of Rio de Janeiro, Brazil. Iheringia, Série Zoologia 97: 472-480.

Milward-de-Azevedo, E. M. V.; J. D. Herzog \& M. A. S. Freitas. 1995. Desenvolvimento ontogenético, potencial reprodutivo e longevidade de Chrysomya megacephala (Fabricius (Diptera: Calliphoridae) em condições de laboratório. Revista Brasileira de Entomologia 39: 493-499.

Moreira, O. I.; C. Martins \& E. M. V. Milward-de-Azevedo. 1996. Avaliação preliminar do desempenho reprodutivo de Nasonia vitripennis (Walker) (Hymenoptera, Pteromalidae) em função do número de gerações. Arquivos Brasileiro de Biologia e Tecnologia 39: 491-195.

Reece, S. E.; D. M. Shuker; I. Pen; A. B. Duncan; A. Choudhary; C. M. Batchelor \& S. A. West. 2004. Kin discrimination and sex ratios in a parasitoid wasp. Journal of Evolutionary Biology 17: 208216.

Rueda, L. M. \& R. C. Axtell. 1985. Guide to common species of pupal parasites (Hymenoptera: Pteromalidae) of the house fly and other muscoid flies associated with poultry and livestock manure. North Carolina Agricultural Research Service Technical Bulletin: $88 \mathrm{p}$.
Schimidt, C. D. 1986. Nasonia vitripennis (Walker) a parasitoid contaminant in fly-rearing facilities. Southwest Entomologist 11: 113118

Slansky, J. R. F. \& M. Scriber. 1985. Food consumption and utilization. In. Compreensive Inss Physiol, Biochem Pharm. Oxford, Pergamon, 160p.

Silveira-Neto, S.; O. Nakano; D. Barbin \& N. A. Villa Nova. 1976. Manual de Ecologia dos Insetos. Ceres, São Paulo, SP, 419p.

Sukontason, K. L.; P. NarongchaI; D. Sripakdee; N. Boonchu; T. Chaiwong; R. Ngern-Klun; S. Piangjai \& K. Sukontason. 2005. First Report of Human Myiasis Caused by Chrysomya megacephala and Chrysomya rufifacies (Diptera: Calliphoridae) in Thainland, and Its Implication in Forensic Entomology. Journal of Medical Entomology 42: 702-704.

Werren J. H. 1983. Sex ratio evolution under local mate competition in a parasitic wasp. Evolution 37: 116-124

Whiting, A. R. 1967. The biology of the parasitic wasp Mormoniella vitripennis (Nasonia vitripennis) (Walker). Quarterly Review of Biology 42: 333-406.

Wylie, H. G. 1963. Some effects of age on parasitim by Nasonia vitripennis (Walk.) (Hymenoptera, Pteromalidae). Canadian Entomologist 95: 881-886.

Wylie, H. G. 1965. Effects of superparasitism on Nasonia vitripennis (Walk.) (Hymenoptera: Pteromalidae). Canadian Entomologist 97: $326-331$. 